\title{
Climate Change Impacts, Agroforestry Adaptation and Policy Environment in Sri Lanka
}

\author{
Mangala De Zoysa', Makoto Inoue ${ }^{2}$ \\ ${ }^{1}$ Department of Agricultural Economics, Faculty of Agriculture, University of Ruhuna, Kamburupitiya, Sri Lanka \\ ${ }^{2}$ Global Forest Environmental Studies, Department of Global Agricultural Sciences, Graduate School of \\ Agricultural and Life Sciences, The University of Tokyo, Tokyo, Japan \\ Email: mangalaxyz@yahoo.com, mangala@agri.ruh.ac.lk, mkinoue@fr.a.u-tokyo.ac.jp
}

Received 4 July 2014; revised 8 August 2014; accepted 19 August 2014

Copyright (C) 2014 by authors and Scientific Research Publishing Inc.

This work is licensed under the Creative Commons Attribution International License (CC BY). http://creativecommons.org/licenses/by/4.0/

cc) (7) Open Access

\section{Abstract}

Despite its low emissions of greenhouse gasses (GHGs), Sri Lanka is considered as a vulnerable small island nation under climate change. Agroforestry, which uniquely integrates trees into land use systems, has historically contributed to climate change adaptation in Sri Lanka. Hence, the promotion of agroforestry practices is vitally important to enhance the resiliency of the country to future climate change. This paper reviews the literature and discusses the adverse impacts of climate change on agriculture and forestry, the effects of adapting agroforestry on climate changes, and important policies for promoting agroforestry adaptation in Sri Lanka. The adverse impacts of climate change on agriculture and forestry are identified as follows: endangerment of natural assets; prevalence of pests, diseases and invasive species; agriculture and forest damage; and high levels of food insecurity. The adaptation of agroforestry impacts climate change by increasing the tree cover outside forests, enhancing forest carbon stocks, conserving biodiversity, reducing risks and damage intensity, maintaining health and vitality, and scaling up multiple benefits. Changing regulations and legislation, developing awareness and capacity, planning for climate-smart agroforest landscapes, offering no-regret options and implementing climate change adjustment programs are discussed as important policy measures. It is concluded that agroforestry, along with favourable policy, has an important role in climate change adaptation by enhancing resilience to climate impacts on farming systems.

\section{Keywords}

Climate Change Impacts, Agroforestry Adaptation, Policy Environment 


\section{Introduction}

The quantity of greenhouse gasses (GHGs) emitted in Sri Lanka does not contribute to global warming (Yamane, 2009). However, climate change impacts in Sri Lanka involve the increasing variability of rainfall intensity and regimes, increasing frequency of storms, increasing mean ambient temperature and sea level rise (Climate Change Secretariat, 2010). The World Bank Group (2011) predicts further increases of climate variability and extreme events across Sri Lanka in the future. The country's mean air temperature increases by $0.016^{\circ} \mathrm{C}$ per year during the period of 1961-1990 (Chandrapala 1996), and it is predicted that the mean temperature may increase by approximately $0.9^{\circ} \mathrm{C}$ to $4^{\circ} \mathrm{C}$ by the year 2100 (Basnayake et al., 2007). The annual average rainfall in Sri Lanka decreases by $144 \mathrm{~mm}$ from 1961 to 1990; this is a decrease of approximately 7\% compared with the period of 1931 to 1960 (Baba, 2010). According to the World Bank Group (2011), historical records from 19742004 indicate that floods and droughts are increasing. The rainfall intensity, amount of rainfall per rainy day and the average rainfall per spell have increased in most parts of the country (Ratnayake \& Herath 2005). El Nino events caused severe drought in Sri Lanka from January to March 1983. Approximately 55\% of the land area, mostly in the dry and intermediate zones, received less than $10 \%$ of the normal rainfall (Yamane, 2009). A flood triggered by $730 \mathrm{~mm}$ of rain was an extreme event and severe climate anomaly in the southern province of Sri Lanka on 17 May 2003 (Cruz et al. 2007).

Sri Lanka is considered as a vulnerable small island nation that is under serious threat from various climate change impacts according to the United Nations Framework Convention on Climate Change (UNFCCC) and the Intergovernmental Panel on Climate Change (IPCC). The impacts of climate change are manifested in all socioeconomic sectors, including agriculture, forest resources, biodiversity, health, energy, and human settlements. The Sri Lankan government ratified the UNFCCC in 1993 and the Kyoto Protocol in 2002. The Ministry of Environment has developed the National Climate Change Adaptation Strategy (NCCAS) for a climate-change-resilient future. The concept of adaptation is closely associated with vulnerability. The UNFCCC and the IPCC have considered the vulnerability and adaptation to climate change as integral components (Yamane, 2009). Farming and forestry have been threatened by the complexity and magnitude of weather-related phenomena (www.Copa-Cogeca.eu). Strengthening adaptation mechanisms by combining agriculture and forestry through sustainable agroforestry management reduces the impacts of climate change. Agroforestry has an important role in climate change adaptation through diversified land-use practices, protected livelihoods and sources of income, enhanced agricultural productivity, and mitigated weather-related production losses, which enhance a region's resilience to climate impacts on farming systems (www.fao.org/forestry2010). Sri Lanka has a long history of integrating trees into land use systems, and many diverse agroforestry systems are in use due to the cultural, climatic and topographic variations of the country.

The authors intend to determine the use of agroforestry in Sri Lanka as a promising land use option for adapting to climate change. Further attempts are made to ascertain the problem of climate change, and agroforestry practices that are restructured from traditional practices to ecologically sound and farmer-based solutions can meet location-specific requirements of policy and receive institutional support. Therefore, this paper reviews the literature and discusses the impacts of climate change on forest and agriculture, the agroforestry adaptation for climate changes and policy environment required to promote agroforestry for climate change adaptation in Sri Lanka.

\section{Adverse Impacts of Climate Change on Agriculture and Forestry}

\subsection{Endangering Natural Assets}

The impacts of climate changes on natural assets both directly and indirectly affect the agricultural and forestry sectors. The mean annual and seasonal daytime maximum and mean annual and seasonal night time minimum air temperatures in Sri Lanka have increased with trends of $0.026^{\circ} \mathrm{C}$ and $0.017^{\circ} \mathrm{C}$ per year, respectively during the period of 1960-2001 (Zubair et al. 2005). The damages of climatic disasters mainly floods, landslides and droughts occurred during 1986-1996 in Sri Lanka are shown in Table 1. According to the National Disaster Management Centre, drought is the most expensive and prolonged hazard in Sri Lanka. The mean rainfall is projected to decrease by $4 \%$ in terms of quantity and spatial distribution compared to historical records (Responsible Tourism Partnership Sri Lanka, 2008). Far more people are severely affected by periodic droughts, especially those in the dry zone of Sri Lanka. The culture-based agriculture that is influenced by the unique hy- 
Table 1. The damage of climatic disasters in Sri Lanka.

\begin{tabular}{|c|c|c|c|c|}
\hline Year & Type of Disaster & Number of deaths & $\begin{array}{l}\text { Number of } \\
\text { affected families }\end{array}$ & $\begin{array}{c}\text { Expenditure for } \\
\text { Relief (Rs. In Millions ) }\end{array}$ \\
\hline 1986 & $\begin{array}{l}\text { Floods \& Landslides } \\
\text { Droughts }\end{array}$ & $\begin{array}{c}40 \\
-\end{array}$ & $\begin{array}{c}118,494 \\
5303\end{array}$ & $\begin{array}{c}13.8 \\
2.4\end{array}$ \\
\hline 1987 & $\begin{array}{c}\text { Floods \& Landslides } \\
\text { Droughts }\end{array}$ & $\begin{array}{l}- \\
-\end{array}$ & $\begin{array}{c}5053 \\
484,925\end{array}$ & $\begin{array}{c}0.6 \\
72.9\end{array}$ \\
\hline 1988 & $\begin{array}{c}\text { Floods \& Landslides } \\
\text { Droughts }\end{array}$ & $\begin{array}{c}03 \\
-\end{array}$ & $\begin{array}{c}26,373 \\
652,363\end{array}$ & $\begin{array}{c}2.9 \\
28.5\end{array}$ \\
\hline 1989 & $\begin{array}{c}\text { Floods \& Landslides } \\
\text { Droughts }\end{array}$ & $\begin{array}{c}325 \\
-\end{array}$ & $\begin{array}{c}86,176 \\
238,426\end{array}$ & $\begin{array}{l}49.1 \\
24.6\end{array}$ \\
\hline 1990 & $\begin{array}{l}\text { Floods \& Landslides } \\
\text { Droughts }\end{array}$ & $\begin{array}{c}37 \\
-\end{array}$ & $\begin{array}{l}157,427 \\
203,794\end{array}$ & $\begin{array}{c}38.7 \\
6.7\end{array}$ \\
\hline 1991 & $\begin{array}{c}\text { Floods \& Landslides } \\
\text { Droughts }\end{array}$ & $\begin{array}{c}34 \\
-\end{array}$ & $\begin{array}{c}55,491 \\
203,794\end{array}$ & $\begin{array}{c}78.9 \\
230.2\end{array}$ \\
\hline 1992 & $\begin{array}{l}\text { Floods \& Landslides } \\
\text { Droughts }\end{array}$ & $\begin{array}{c}25 \\
-\end{array}$ & $\begin{array}{c}71,080 \\
-\end{array}$ & $\begin{array}{c}154.6 \\
-\end{array}$ \\
\hline 1993 & $\begin{array}{c}\text { Floods } \\
\text { Landslides } \\
\text { Droughts }\end{array}$ & $\begin{array}{c}06 \\
29 \\
-\end{array}$ & $\begin{array}{c}210,874 \\
870 \\
16,383\end{array}$ & $\begin{array}{c}30.0 \\
4.42 \\
7.6\end{array}$ \\
\hline 1994 & $\begin{array}{l}\text { Floods } \\
\text { Landslides } \\
\text { Droughts }\end{array}$ & $\begin{array}{c}- \\
08 \\
-\end{array}$ & $\begin{array}{c}353,409 \\
284 \\
-\end{array}$ & $\begin{array}{l}37.4 \\
0.63 \\
0.62\end{array}$ \\
\hline 1995 & $\begin{array}{c}\text { Floods } \\
\text { Landslides } \\
\text { Droughts }\end{array}$ & $\begin{array}{l}- \\
- \\
-\end{array}$ & $\begin{array}{c}353,409 \\
484 \\
-\end{array}$ & $\begin{array}{c}37.4 \\
2.9 \\
-\end{array}$ \\
\hline 1996 & $\begin{array}{l}\text { Floods } \\
\text { Landslides } \\
\text { Droughts }\end{array}$ & $\begin{array}{c}03 \\
- \\
-\end{array}$ & $\begin{array}{c}8238 \\
75 \\
199,535\end{array}$ & $\begin{array}{c}12.2 \\
0.05 \\
424.9\end{array}$ \\
\hline
\end{tabular}

Source: http://www.iedm.ges.kyoto-u.ac.jp/workshop/IEDM\%20Forum2006/rekha\%20nianthi.pdf

draulic civilisation in Sri Lanka and that has been practiced for centuries has also been affected. Vulnerability mapping performed by the Ministry of Environment in 2011 shows that the irrigation sector's vulnerability to drought exposure is widespread, but it is more concentrated in the dry zone. Approximately $55 \%$ of the land area, mostly in the dry and intermediate zones, received less than $10 \%$ of the normal rainfall. Climate change impacts are critical for the continuation of traditional cultural practices at the local level due to the loss of species. Biodiversity in most areas of Sri Lanka is vulnerable to the impacts of climate change. From the 58 assessed dipterocarps plant species which are remarkably endemic in Sri Lanka, 42 species mostly confined to the Wet Zone are threatened (Climate Change Secretariat, 2010). Forests play an important role in regulating water in Sri Lanka, which critically depends on the staple foods, power generation and drinking water. Forest resources in Sri Lanka decreased from 36\% of the total land area in 1990 to 29\% in 2006 (Responsible Tourism Partnership Sri Lanka, 2008). The total forest cover of 1.94 million hectares in 1999 is estimated to have decreased by $2 \%$ 3\% in 2012 (Climate Change Secretariat, 2010). In contrast, heavy rains erode top soil and wash away fertilisers and other chemicals. It has been estimated that approximately $30 \mathrm{~cm}$ of soil has already been eroded from upland tea plantations (Wijeratne, 1996). The projected sea level rise in Sri Lanka, i.e., $0.3 \mathrm{~m}$ by 2010 and $1.0 \mathrm{~m}$ by 2070, would adversely influence the coastal environment, agriculture, forest, biodiversity, health, energy, and human settlements (Natcom, 2000). It has been estimated that for a rise of sea level in $0.3 \mathrm{~m}$ and $1 \mathrm{~m}$, the inundation will be in the range $41 \mathrm{~km}^{2}$ and $91.25 \mathrm{~km}^{2}$ respectively for lowlands along the southwest coast (Weerakkody, 1996). The Indian Ocean tsunami of 26 December 2004, an extreme event, affected over two-thirds of the coastline and destroyed assets, infrastructure, agriculture and forests; the disaster claimed over 35,000 human lives in Sri Lanka (Mattsson et al., 2009).

\subsection{Prevalence of Pests, Diseases and Invasive Species}

Sri Lanka was self-sufficient regarding food and practiced agriculture with low external inputs prior to intro- 
ducing modern agriculture. Under traditional diverse system of cultivation, mixed cropping was more popular in rain-fed conditions and was unlikely to promote pests or spread disease. Traditionally grown crop varieties were well adapted to the environment, and pest attacks did not occur at significant levels. Currently, crop vulnerability to disease, pest infestations, and choking weeds have been increased by the altered weather patterns. Less diverse farms and forests face a major environmental challenge regarding the climate-induced risk of pests and diseases. Warmer temperatures due to climate change generally develop conditions for the proliferation of plant pests and diseases. Climate change affects pest and disease incidence and virulence because diseases and insect populations are strongly dependent upon temperature and humidity. Increases in the pest and disease problems of coconuts in Sri Lanka due to increasing air temperatures increase the investment in pest control (Peiris et al. 2004). Climate change impacts are expected as abrupt invasions and changes in population dynamics. Invasive alien species have spread at an unprecedented rate and dominate over native and natural species; this trend has severely threatened natural ecosystems and biodiversity in Sri Lanka (Mattsson et al., 2009). The accelerated spread of invasive alien species as a result of climate change impacts is affecting agricultural lands and diminishing agricultural production in many areas of Sri Lanka. Climate change has increased the risk of diseases also in some tree species that have grown for many years. Forest species, mainly Eucalypt species and acacias, and many other perennial crops are affected by the C. quinqueseptatum pathogen (Booth et al., 2000).

\subsection{Agriculture and Forest Damage}

The potential impacts of climate changes on the agricultural and forestry sectors include increased damage to crops, trees and soils due to drought, flooding and land degradation. The broad impacts of climate change on agriculture in Sri Lanka are the impacts of temperature and precipitation on crop growth. With the increase in temperature, crop injuries are possible because crops are cultivated in Sri Lanka at optimum temperature ranges. Exceeding ambient temperature over $35^{\circ} \mathrm{C}$ even for just 60 - 90 minutes at the flowering stage, can cause crop damages for paddy. Increased temperatures have negatively affected high-value crops, mainly vegetable and potato cultivations of the country (Eriyagama, et al., 2010). Harvesting crops according to the ancient seasons of "Yala" and "Maha" based on the timing of monsoons in Sri Lanka has shifted in recent decades. The variability of rain from monsoons and convection has increased significantly in recent decades due to climate change and has become a recurrent problem in crop production (Punyawardena, 2007). Paddy farming output is estimated to decrease by $20 \%-30 \%$ in the next 20 to 30 years due to the negative impact of monsoonal changes (Baba, 2010). Major irrigation in Sri Lanka offers protection from drought; however, during severe droughts, there is no water in the irrigation channels and crops fail (Yamane, 2009). Prolonged droughts also affect plantation crops such as tea, rubber and coconut and minor export crops such as cocoa and coffee, which account for slightly more than 700,000 hectares of agricultural land in the wet and intermediate zones. Empirical findings show that the growth and yield of tea are adversely affected by the increases in temperature, soil moisture deficits, and saturation vapour pressure deficits at low elevations (Sivakumar et al., 2005). Except in the upper wet zone, rising temperatures and diminishing rainfall reduce tea yields in many tea-growing regions. The optimum rainfall in different tea growing regions varies from 223 to $417 \mathrm{~mm}$ per month. The productivity of made tea could reduce by 30 - $80 \mathrm{~kg}$ with the reduction of monthly rainfall by $100 \mathrm{~mm}$ (Wijeratne et al. 2007). Climatic factors, mainly rainfall and temperature, influence the yields of coconuts, which are grown as a rain-fed crop in Sri Lanka. Extended dry spells and excessive cloudiness during the wet season can reduce coconut yields and cause annual losses between US\$32 and US\$73 million (Fernando et al. 2007). Somaratne \& Dhanapala (1996) have estimated that increased temperature and rainfall would result in a decrease of the tropical rain forest of $2 \%$ $11 \%$ and an increase of the tropical dry forest of $7 \%-8 \%$. Shifting the Dry Zone spread into the Intermediate Zone and the Intermediate Zone spread into the Wet Zone from $10 \mathrm{~m}$ band where they could become more water scarce and drier is predicted due to climate change. These forests and the species that would contain by the forest area of $1248 \mathrm{~km}^{2}$ within the intermediate zone/dry and $544 \mathrm{~km}^{2}$ within the intermediate zone/wet zone could be severely affected (Climate Change Secretariat, 2010). The existing ambient temperature is at or very near the upper margins of the optimum temperature range for many wild relatives of crops in the dry zone, which is also threatened by climate change. It is predicted that under extreme drought conditions, fire hazards increase in forests. Wild relatives, including five species of wild pepper, eight species of wild cinnamon, ginger, cardamom and nutmeg, that occur in the natural forests of the wet zone are vulnerable to the threat of climate change. Medicinal plants, ornamental plants, timber species and wild relatives of non-food crop species are also among the 
threatened wild varieties in the natural forests of Sri Lanka (Dela, 1998). An increase in the volume of sea water entering estuaries or lagoons due to climate change adversely affects the peripheral agricultural lands and crops in Sri Lanka. A tsunami in 2004 seriously damaged the agricultural and forestry sectors in Sri Lanka via seawater intrusion, salinisation of lands and water body contamination (Mattsson et al., 2009).

\subsection{High Levels of Food Insecurity}

Sri Lanka's vulnerability to climate-change-induced natural disasters, such as floods, droughts, cyclones, landslides, and epidemics, substantially threatens food security. Sri Lanka is predicted to be one of the hotspots of food insecurity in the Asia-Pacific region. Food production in South Asia is alarming with the shifts in the monsoonal rainfall patterns due to global warming. Food security is often directly or indirectly dependent on agricultural and forest ecosystem services. The vulnerability of water resources and agricultural output in Sri Lanka is the key challenge to national food security in the wake of climate change. Climate change impacts in the form of prolonged and more frequent droughts in Sri Lanka reduce the availability of water for rain-fed agriculture and often reduce crop production. Nellemann et al. (2009) predict a further decrease of $0 \%-15 \%$ in agricultural productivity of the country by 2080 . Climate change impacts can be large in the agriculturally intensive areas located in the dry zone where some production is already experiencing water stress. Field crops, including coarse grains, grain legumes, oil seeds and condiments that are grown on rain-fed upland areas in the dry and intermediate zones have also been adversely affected. The irrigation sector's vulnerability to drought exposure is widespread but more concentrated in the dry zone where there is high dependency on irrigation for agriculture. The annual cropping intensities of major irrigation schemes of the country are low and generate lower annual incomes for farmers (Dharmasena, 2010). Agriculture under small-scale irrigation is confined to one season only in some years due to the drought. Farmers face problems regarding the availability of groundwater for agriculture when droughts are frequent (Jinapala, 2010). Impacts of droughts and saline water intrusion in the coastal areas, combined with the increasing demands on freshwater resources due to expanding human settlements in Sri Lanka, are likely to reduce water availability and affect both irrigated and rain-fed agriculture (The World Bank Group, 2011). In Sri Lanka, a large proportion of the poor population who are living in vulnerable areas are dependent on weather-reliant industries, such as agriculture, forestry and fisheries. Climate change impacts on water resources and the agriculture sector may seriously effect food production, the livelihoods of farmers and the economy in Sri Lanka. The communities that already have high levels of food insecurity, environmental degradation and limited options for coping with adverse weather conditions are severely affected. Severe droughts impacted over 3.5 million people of the country who required emergency assistance in the form of food, water, and medical assistance between 2000 and 2005 (UNESCAP, 2007). Preliminary agricultural vulnerability mapping suggests that the Nuwara Eliya, Badulla, Moneragala, Ratnapura and Anuradhapura are as of the country are more sensitive to climate change due to their heavy reliance on primary agriculture. Further, they have a lower adaptive capacity and face higher vulnerability due to their lower levels of infrastructural and socioeconomic assets.

\section{Adaptation of Agroforestry to Climate Change}

\subsection{Increase Tree Cover Outside Forests}

All of the technically suitable land areas for forestation cannot be devoted to plantation forestry because they are agricultural lands that support local populations. A more appropriate land use system could be agroforestry, specifically, growing trees in conjunction with agricultural crops. Agroforestry systems in Sri Lanka provide corridors that connect distant reserves through the matrix effect on species diversity in landscape mosaics with native tree cover and through the persistence and movement of species across landscapes. Agroforestry in the rural landscape contributes to environmental sustainability and benefits climate change adaptation by storing carbon, halting land degradation, and fixing nitrogen. Home gardens, which are widespread and vary in species composition and tree density, are the best developed agroforestry system in Sri Lanka. Home garden systems cover $22 \%$ of the land area and are considered forest analogues that supply more than $70 \%$ of the timber and $80 \%$ of the fuel wood outside natural and planted forests in Sri Lanka (UN-REDD Program, 2012). Home gardens in Sri Lanka offer great potential for restoring and increasing forest cover and connectivity. The district-wise changes of the forest cover in home gardens during 1983-1999 are shown an increase except Mulathive and Ratnapura 
Districts where forest cover shows a decrease (Figure 1). In many parts of the wet zone, home gardens represent an important type of land use at the margins of larger rainforest fragments and still occur in landscapes where natural forest is scarce. The Kandyan home gardens (KHGs) are traditional systems of agroforestry found around the Kandy District in the central highland of Sri Lanka that have evolved into unique ecosystems and provide numerous goods and services. KHGs cover approximately $40 \%$ of the Kandy District and primarily contain perennial and semi-perennial trees, shrubs and up to 30 different crops (Kallesoe \& De Alvis, 2004). Presently, approximately 9,851,250 home gardens cover $9701 \mathrm{sq} \mathrm{km}$ comprising $2220 \mathrm{sq} \mathrm{km}$ of tea estates, 1158 sq $\mathrm{km}$ of rubber plantations, and $3948 \mathrm{sq} \mathrm{km}$ of coconut plantations within the coconut triangle; privately held woodlots also provide additional tree cover outside forests (UN-REDD Program 2012).

The government of Sri Lanka implemented the Participatory Forestry Project (PFP) during 1993-2000 by promoting co-management and agroforestry with the intention of reducing deforestation and improving house

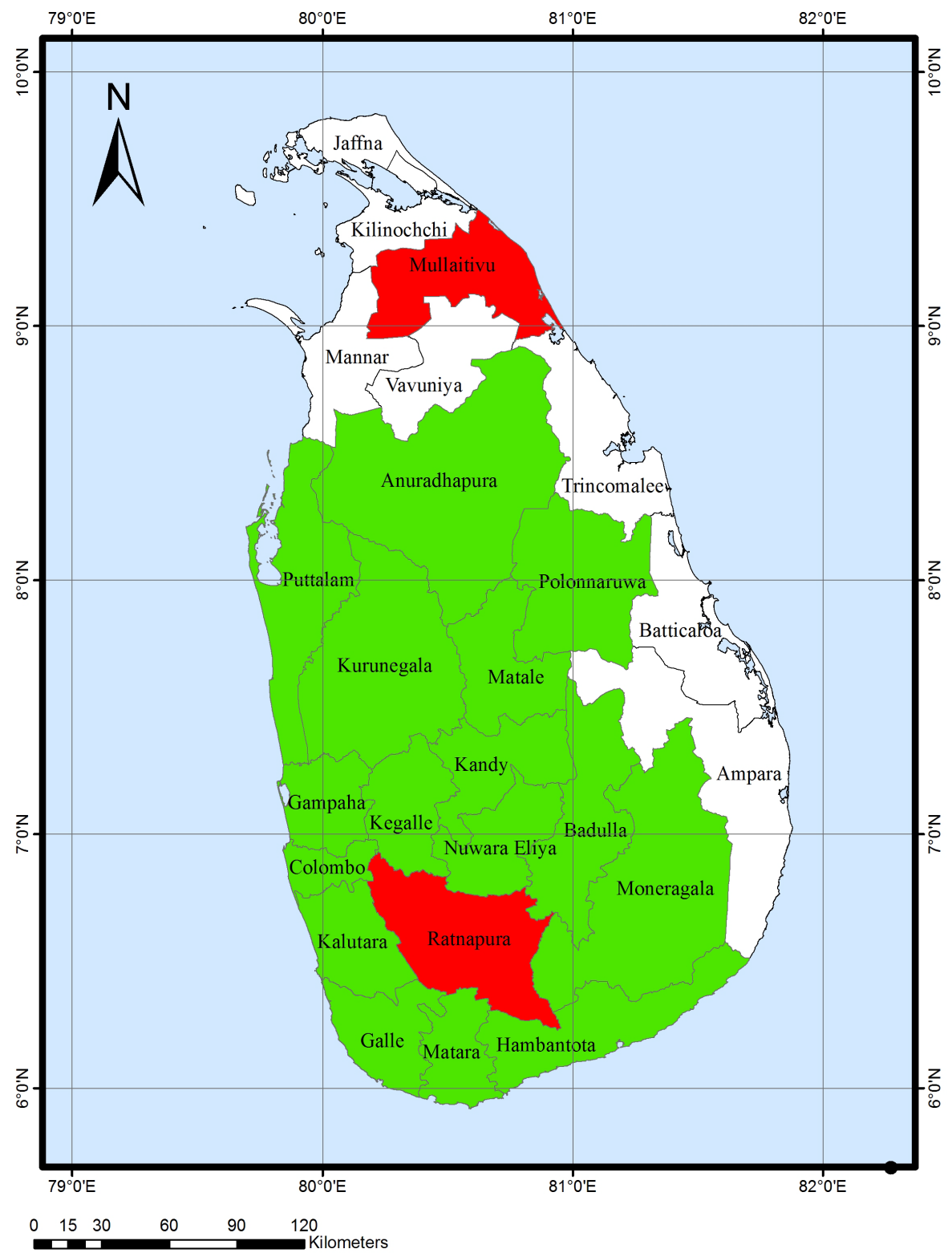

Figure 1. District-wise changes of forest cover in home gardens 1983-1999. Green colour symbolizes an increase, red colour symbolizes a decrease and white colour symbolizes no data of forest cover of Home gardens Source: Näsström, R. \& Mattsson, E., 2009. 
hold livelihoods. The PFP included the farmers' woodlots scheme, protective woodlots, home garden development, and the village reforestation system for benefit sharing from agroforestry (UN-REDD Program, 2012). The project aimed to establish a total of 14,750 hectares of reforested land, 9000 hectares of homestead gardens, 4000 hectares of farm wood lots (FWL), 1500 hectares of protective wood lots (PWL) and 250 hectares of miscellaneous plantings over the 7-year project period (Kallesoe \& De Alvis, 2005). The Upper Watershed Management Project (UWMP) was initiated in 1998 and implemented until the year 2005 to address management issues in four major watersheds in Sri Lanka, i.e., Uma, Kirindi, Walawe and Kalu, and to suggest sustainable management approaches. Maintaining and increasing forest cover, applying soil conservation measures, and integrating homestead garden developments into the broader basin management are the main activities related to watershed conservation and rehabilitation (Kallesoe \& De Alvis, 2005). The government of Sri Lanka declared Gliricidia sepium as the fourth main plantation crop to fall under the purview of the Ministry of Plantation Industries. Popularising Gliricidia plantations would increase the present forest cover of 1.7 million ha to a more acceptable level. Gliricidia is grown in extensive areas of scrub land and has minimal value for food crops due to inadequate rainfall and low fertility, but it is suitable for growing short rotation fuel wood

(www.scribd.com/doc/95318104). Help Green (Pvt.) Ltd. initiated in 1988 has developed 600 ha of teak woodlots in non-forest lands and expected to increase to 5000 ha in which private investments are attracted by offering substantial economic returns from timber sales and by contributing towards environmental health. They have expanded their business model to include agroforestry by intercropping cash crops, such as soybeans, chilies, sweet potatoes, ginger and sunflowers, with teak trees to increase revenue and stimulate tree and eco-tourism services (Kallesoe \& De Alvis, 2005). Some other private companies are planting the trees of timber species such as teak, mahogany, agar-wood and sandalwood on non-forest lands, for the general public to invest. Presently, touchwood has invested for about 1400 ha of plantations, while Sadaharitha Plantations has invested over 405 ha of teak and 30 ha of sandalwood (UN-REDD Program 2012). In line with the Green villages and "Dayata Sevena" national tree planting programs, local authorities, schools, home garden owners and the private sector are involved in agroforestry systems to enhance timber resources, canopy cover, and carbon stocks, which can be considered under REDD+ in Sri Lanka (UN-REDD Program 2012). Integrating agroforestry characteristics into Agro-well-based agriculture in the Yan Oya in dry zone of Sri Lanka has led to the development of canopy cover and helped to conserve soil moisture, reduce soil erosion, and maintain bio-diversity. Areas with perennial canopies have been increasing over all well-based lands from a mere $0.3 \%$ in 1994 to 6\% in 2004 with the decrease of shifting cultivation lands from 30\% to 22\% during the same period (Perera, 2010).

\subsection{Enhance Forest Carbon Stocks}

Sri Lanka is not producing GHGs that induce global warming and climate change. The CO2 emission in Sri Lanka is less than 0.1 percent of the total global $\mathrm{CO}_{2}$ emissions and is marginal relative to other countries (Baba, 2010). Green House Gas (GHG) emission levels in Sri Lanka are low in both absolute $\left(26.1 \mathrm{Mt}^{\mathrm{CO}_{2}}\right.$ ) and per capita terms (1.3 $\mathrm{t} \mathrm{CO}_{2}$ ), excluding land use change in 2005 (Mattsson et al., 2012). It has been estimated that the baseline deforestation emissions in Sri Lanka amounted to $17 \mathrm{Mt} \mathrm{CO}_{2} /$ year in the 1992-1996 period. According to the Responsible Tourism Partnership Sri Lanka (2008), 2 million hectares of forest in Sri Lanka store approximately 21 Mtons of $\mathrm{CO}_{2}$ per hectare for a total of approximately 40 million tons of carbon. Establishing forestry and vegetation on non-forested lands and promoting mixed cropping to ensure fertile soil in the long-run reduce the emissions in Sri Lanka. Moving from low-biomass land-use systems, such as grasslands, agricultural fallows and permanent shrub lands, to agroforestry systems will produce a net gain of $\mathrm{C}$ stocks by sequestering $\mathrm{CO}_{2}$ via biomass $\mathrm{C}$ storage (Roshetko et al., 2007). Tree species and management of agroforestry systems also influence carbon storage. A substantial increase of agroforestry area will have a large impact on the flux and long-term storage of $\mathrm{C}$ in the terrestrial biosphere. The energy in Sri Lanka also mainly originates from clean sources, such as biomass and hydro power. The use of biomass, which is produced sustainably for energy generation, does not lead to a net build-up of $\mathrm{CO}_{2}$ levels in the atmosphere. Biomass that is produced in nonforest land is cheap and easy to attain; therefore, it is a popular option and viable for the mostly poor rural population of the country. As a clean source, primary solid biomass produces $54.2 \%$ of the energy requirement of rural population in Sri Lanka (Baba, 2010).

Non-forest lands, such as home gardens, tea estates, rubber plantations, coconut plantations within the coconut triangle and privately held woodlots, provide additional tree cover and are a major source of fuel wood and 
timber. Current data on the scale of agroforestry planting or of trees outside forests and their contributions to carbon stocks are not available in Sri Lanka. However, different forms of agroforestry, home gardens and boundary plantings have been well recognised as potential long-rotation systems that mitigate $\mathrm{CO} 2$ and sequester sizeable quantities of C in plant biomass (Albrecht \& Kandji, 2003). Home gardens in Sri Lanka contain a significant fraction of the total above-ground biomass carbon stock in the terrestrial system, and this proportion has increased from almost one-sixth in 1992 to nearly one-fifth in 2010. Home gardens store significant amount of carbon, with above ground biomass carbon stocks with a mean value of $35 \mathrm{Mg} \cdot \mathrm{C} \cdot \mathrm{ha}^{-1}$ in dry zone while 87 $\mathrm{Mg} \cdot \mathrm{C} \cdot \mathrm{ha}^{-1}$ in wet zone in the terrestrial system in Sri Lanka (Mattsson et al., 2013). The tree density per hectare ranged from 338 in dry zone home gardens to 2108 in wet zone home gardens; these values are reflected in the higher carbon stock estimates within the wet zone home gardens (Mattsson et al., 2012). Agroforestry, the treebearing agricultural land-use systems, sequester carbon at higher rates than systems containing only annual crops, pastures, or grasslands; the agroforestry sequestration rate is generally $0.2-3.1 \mathrm{t} \cdot \mathrm{C} \cdot \mathrm{ha} \mathrm{a}^{-1}$ per year (Pandey, 2002). Home garden agroforestry systems in Sri Lanka are a valuable part of the country's tree cover and act as important carbon sinks. Large coconut trees that are mixed with many small trees are common in rich, diverse home gardens in southern Sri Lanka. Coconut (194.4 t.C/ha) and home garden (107.9 t.C/ha) store a high volume of carbon stocks (Table 2). In addition to providing $\mathrm{C}$ inputs, such as root biomass, litter and prunings to the soil, agroforestry trees in agricultural fields often reduced soil erosion, which is a crucial process in the soil $\mathrm{C}$ dynamics. The majority of agroforestry systems produce non-wood products, such as fruits, vegetables, spices, oils, and resins, and are harvested with a negligible impact on the $\mathrm{C}$ stock of a system compared to the harvest of wood products (Roshetko et al., 2007). Hence, changes in carbon stocks within home gardens, forest analogue systems, are considered to be of paramount importance for a national REDD+ Programme in Sri Lanka (UNREDD Program, 2012). Agroforestry in Sri Lanka, which introduces trees into existing agricultural systems, falls into the Clean Development Mechanism-Afforestation/Reforestation (CDM-AR) eligible categories. The clean development mechanism (CDM) assists developing countries with the multiple goals of poverty reduction, environmental benefits and cost-effective emissions reductions.

\subsection{Conserve Biodiversity}

The need for biodiversity conservation in human-dominated landscapes is greater today as species are forced to persist in degraded and secondary habitats outside forest reserves. Agroforestry impinges on biodiversity by reducing exploitation of protected areas, increasing biodiversity in a human-dominated or working landscape, and increasing the species and within-species diversity of trees in farming systems (Garrity, 2004). Traditional farming systems in Sri Lanka have been developed by farmers who manage production systems to best suit their local conditions. The main crops habitats are rice fields, crop plantations, vegetable plots, chena (similar to shifting cultivation) plots and home gardens. The traditional species of these land types are clearly resistant to diseases and insect pests, suitable for variable soil and climate conditions and well adapted to their new environments, but they are also still genetically similar to their wild relatives (MoENR, 2009a). An average of 40\% of the tree species in traditional forest gardens in Sri Lanka is endemic. Ariyadasa (2002) found 400 different woody species in home gardens in Sri Lanka covering $87 \%$ of the country where the majority of tree species were indigenous or endemic with multi-purpose uses. An enormous potential for adaptation to progressive climate change is provided by both inter- and intra-specific agricultural biodiversity. Agroforestry conserves biodiversity, even if the species composition and biodiversity of the lost natural forests are not the same, depending on how the agroforests are managed and how close they are to the natural forests in terms of time and space. Presently, the forest gardens in Sri Lanka are structurally and functionally analogous to the natural forest and are established in alleys with different combinations of seasonal crops, cash intercrops, fodder-dairy, and woodlots (Table 3). Based on variations in soil, annual rainfall and altitude, 46 agro-ecological regions have been identified in Sri Lanka. Maintaining agroforests is therefore a good means to maintain a certain level of biodiversity. The change in species composition may sometimes be an advantage if the new species are better adapted to changing conditions. Home gardens in southern Sri Lanka have a rich diversity with many smaller fruit trees mixed with larger trees, such as coconut. A study of home garden vegetation conducted in semi-urban home gardens in the Western Province revealed as many as 101 species, including coconut, rubber, fruit and timber, comprising over 2817 individuals; the stem density was over 400 trees/ha (Dela, 1998). The sustainable management of Kandyan Home Gardens (KHGs), the traditional systems of agroforestry found in the central high- 
Table 2. Mean values of basal area, standing biomass and carbon stock of the different forest types.

\begin{tabular}{cccccc}
\hline & Natural Forest & Coconut & Casuarina & Home garden & Mangrove \\
\hline BA $\left(\mathrm{m}^{2} / \mathrm{ha}\right)$ & 75.6 & 62.4 & 36.3 & 31.2 & 26.4 \\
Standing biomass $\left(\mathrm{m}^{3} / \mathrm{ha}\right)$ & 702.4 & 457.5 & 285.2 & 253.8 & 222.5 \\
Carbon stock $(\mathrm{t} \cdot \mathrm{C} / \mathrm{ha})$ & 294.8 & 194.4 & 121.5 & 107.9 & 94.6 \\
\hline
\end{tabular}

Source: Mattsson et al., (2012).

Table 3. Species list of an 0.5 ha analog forest.

\begin{tabular}{|c|c|c|c|}
\hline Forest layer & Crop/Tree & Botanical Name & Number \\
\hline Emergent & $\begin{array}{c}\text { Areca nut } \\
\text { Eucalyptus } \\
\text { Fishtail palm (kitul) }\end{array}$ & $\begin{array}{l}\text { Areca catechu } \\
\text { Eucalyptus sp. } \\
\text { Caryota urens }\end{array}$ & $\begin{array}{l}54(6.9) \\
6(0.8) \\
15(1.9)\end{array}$ \\
\hline Canopy & $\begin{array}{c}\text { Avocado } \\
\text { Breadfruit } \\
\text { Mango } \\
\text { Ceylon olive (weralu) } \\
\text { Papaw (papol) } \\
\text { Jak fruit (kos) } \\
\text { Sapu }\end{array}$ & $\begin{array}{c}\text { Persea americana } \\
\text { Artocarpus incisa } \\
\text { Mangifera indica } \\
\text { Elaeocarpus glandifuler } \\
\text { Carica papaya } \\
\text { Artocarpus integrifolia } \\
\text { Michelia champac }\end{array}$ & $\begin{array}{l}16(2.1) \\
5(0.6) \\
15(1.9) \\
2(0.3) \\
18(2.3) \\
2(0.3) \\
7(0.9)\end{array}$ \\
\hline Sub-canopy & $\begin{array}{c}\text { Banana } \\
\text { Cherimoya (anoda) } \\
\text { Curry leaf tree (karapincha) } \\
\text { Orange } \\
\text { Lime }\end{array}$ & $\begin{array}{l}\text { Musa sapientum } \\
\text { Anona cherimolia } \\
\text { Murraya koenigii } \\
\text { Citrus sinensis } \\
\text { Citrus aurantifolia }\end{array}$ & $\begin{array}{l}30(3.9) \\
9(1.2) \\
9(1.2) \\
20(2.6) \\
20(2.6)\end{array}$ \\
\hline Shrub & $\begin{array}{c}\text { Coffee } \\
\text { Cardamom }\end{array}$ & $\begin{array}{l}\text { Coffea arabica \& robusta } \\
\text { Elletaria cardamomum }\end{array}$ & $\begin{array}{l}270(34.7) \\
280(36.0)\end{array}$ \\
\hline Total & & & $778(100)$ \\
\hline Ground cover & $\begin{array}{c}\text { Ginger } \\
\text { Turmeric } \\
\text { Yam } \\
\text { “Arrowroot” (hulankeriya) }\end{array}$ & $\begin{array}{l}\text { Zingiber officinale } \\
\text { Curcuma domestica } \\
\text { Dioscorea spp. }\end{array}$ & 18 plots of $4 \mathrm{~m}^{2}$ each \\
\hline
\end{tabular}

(Percentages are in parenthesis); Source: After Nuberg, I. K., \& Evans, D. G. (1993).

land of Sri Lanka that cover approximately 40\% of the Kandy District, conserves a wide range of biodiversity areas containing more than 30 different crops, primarily perennial and semi-perennial trees and shrubs (Kallesoe \& De Alvis, 2005). Beverage crops, including tea, coffee and cacao, are successfully cultivated under a large number of leguminous and other shade trees. Pepper under shade trees, mixed spices and beverage crops under shade trees and cardamom grown beneath forest cover are the three main agroforestry subsystems that grow spice crops under shade trees. Except cinnamon, all perennial spices are cultivated in agroforestry types of farming systems. Spices have been cultivated over 50,000 ha of wet zone accounting for about 6\% of the land under all perennials crops (Lindara et al., 2004). Horticultural plantings of native species in landscaping, gardens, roadside areas, and parks are classic examples of species responding in different locations of the country as the climate changes. Climate Change Secretariat (2010) has recognised that the conservation of watersheds and wetland biodiversity are of crucial importance when adapting to climate change in Sri Lanka.

According to the Climate Change Secretariat (2010), functionally diverse vegetation in Sri Lanka tends to adapt to climate change and climatic variability better than impoverished vegetation, while genetically diverse species appear to have more potential for long-term persistence. The resources in biodiversity areas include food, fuel, fibre, wood products, timber, medicines, biomedical materials, ornamental species of commercial value, raw materials for industry, and areas for recreation and aesthetic enjoyment, which are vital to meet the consumptive and economic needs of the country. Hence, conserving and sustainably managing biodiversity of agroforestry is of critical importance to reduce the negative impacts of climate change on biodiversity, ecosystem services, and economic advancement in Sri Lanka. 


\subsection{Reduce Risk and Intensity of Damage}

Reducing the risk and intensity of damage has become a major concern for many farmers and foresters in Sri Lanka under changing climatic conditions. From the elderly farmer's descriptions of farming patterns, there is evidence that the climate is getting hotter and drier. One possibility to achieve analogue forestry is to use cropping systems that mimic the structure and successional processes of a tropical forest to adapt to the climate change impacts. Resilience can be increased through the reduced exposure of cultivated plants to environmental stresses by planting combination of trees and crops as agroforests. Agroforestry systems in Sri Lanka with multi-layer canopy, which cover the ground, improve soil structure by incorporating tree biomass into the soil and reducing soil erosion to create a multi-layer defence mechanism against rain and wind erosion and to increase the infiltration capacity. Traditional agroforestry systems in Sri Lanka have been widely practiced throughout history as a means of slowing soil and other environmental degradation. Shadow crops also contribute to additional protection against extreme rainfall and are less exposed to soil erosion. The complex and diverse landscape structure created by agroforestry systems is important for biological pest control by supporting populations of natural enemies of agricultural pests (Pandey, 2002). Planting multipurpose trees on farms offers an alternative to adopting organic practices and integrated pest management and can reduce dependence on pesticides. Diversified productions of agroforestry systems are a form of risk avoidance and ensure food production even under the current agricultural crises. The government program "Api Wawamu Rata Nagamu” (Let us grow, and uplift the nation) launched in 2007 to develop 375,000 home gardens. The national tree planting program called the "Divi Neguma" (Livelihood Development) aimed to establish 1.5 million home gardens to achieve self-sufficiency of vegetables and to reduce vegetable prices; the number has further increased to 2.5 million home gardens (Kumari et al. 2009). Due to the complexity of measures that may have contradictory effects, there is a tendency for integrated management practices to include different treatments that help maintain the vitality of the agroforests, including timely agricultural and silvicultural practices and species mixing. The increasing salinity of low-lying coastal areas due to sea level rise has devastating effects on productive agricultural land. Introducing strips of vegetation has reduced the salinity level and created favourable conditions for crop diversification. Use of several adaptation strategies by home gardeners in Sri Lanka not only functions as a way to reduce pressure on natural forest land but also resists climate change impacts. Home garden structures in Sri Lanka exhibited resilience against and protection from the 2004 tsunami. In the Hambantota District, houses with home gardens or in the vicinity of neighbours' home gardens received less damage than those without home gardens during the tsunami (Mattsson et al., 2009).

The economies of tropical small island countries are based on diverse agricultural systems and are subject to fewer impacts from climate change. Due to the high sensitivity of agriculture to the prevailing climate variability, the dependency of households on home gardens to secure their livelihoods is increasing. The objectives of the Climate Change Enabling Activity Project (CCEAP) in Sri Lanka initiated in 2001 were to develop an adaptation strategy and to recommend mitigation measures needed to offset and limit potential impacts of climate change on the different sectors of the national economy (Kallesoe \& De Alvis, 2005). Agroforestry systems provide higher cash incomes and greater purchasing power for farmers, especially when agriculture is not practiced or when crops fail. A study of intercropping of coconuts in the wet and intermediate wet zones has revealed that farmers prefer bananas, black pepper, coffee, and ginger (in order) as intercrops. The main factors that influenced the farmers' preference for crops are profitability, marketing facilities and convenience (MoENR, 2009b). Considering the urgent national challenge, the goal of the "Api Wawamu Rata Nagamu" programs are to reduce living costs and imports of food products, enhance food security, maintain environmentally friendly traditional agriculture methods and identify avenues to test new technologies (Kumari et al. 2009). Dendro plantations in semi-utilised lands, lands used for tea and coconut, and largely unutilised lands are encouraged to supply fuel wood for alternative power generation (www.scribd.com/doc/95318104).

\subsection{Maintain Health and Vitality}

The main threats to health and vitality of agriculture and forests are extreme weather events, pests and diseases. The diversity of agroforestry usually enhances biodiversity and is useful for maintaining health and vitality. Promoting diverse age classes, species mixes, structural diversities, and genetic diversity in agroforestry systems in Sri Lanka provide the most practical opportunities for resetting ecological trajectories. Other intrinsic attrib- 
utes of the land use activity of agroforestry include the low inputs and ecological security. Most of the agroforestry systems of the country are characterised by high levels of on-site nutrient conservation, similarly to selfnourishing natural forest ecosystems. Kandyan Home Gardens (KHGs), the traditional systems of agroforestry in Kandy, have evolved into unique ecosystems that provide numerous goods and services and maintain promising health and vitality. In these complex agroforestry systems, the decline in soil fertility is considered minimal despite the continuous harvests of crops, wood and other products. Soil physical and chemical properties are improved by returning the abundant litter and pruned biomass to the soil, along with the decay of roots. Smallholder farmers in ecologically marginal areas of Sri Lanka are practicing alley cropping as an appropriate agroforestry technology restores the fertility of degraded soil and provide other services, such as erosion control (Nanayakkara, 1991). Boundary plantings and live fences in home gardens in Sri Lanka, which are more densely spaced, comprise a number of different species that modify microclimates, improve water conditions, and improve soil characteristics positively effect crop production. Extending agroforestry, especially to uplands and very steep slopes, increases climate resiliency, provides different sources of income, and reduces land erosion. The UWMP addressed management issues, such as applying soil conservation measures, integrating homestead garden development activities related to watershed conservation, and rehabilitating the four major watersheds (Kallesoe \& De Alvis, 2005). A structure of alleys created by hedgerows of nitrogen-fixing woody species planted along the contour is characterised by a sequence of two alleys of seasonal crops and one alley of perennial crops in watersheds. A block of alleys is dedicated to fodder production for a livestock system or a woodlot system in which farmers are persuaded to maintain perennial vegetative cover on as much of the land as possible (Nuberg \& Evans, 1993). The KHGs are often found on steep slopes, and the ground cover of agroforests protects lands from severe erosion and floods (Kallesoe \& De Alvis 2005). The organic production of fruits, tea and spices in agroforestry systems has expanded rabidly in Sri Lanka over the last few decades for producing environmentally friendly products, and limiting the use of chemicals and artificial fertilizer. Over 3300 farmers have cultivated 14,250 ha of land with organic products and another 4550 ha were under conversion in 2000 now generating more than 31 million USD a year while providing environmental services (Kallesoe \& De Alvis (2005). A study conducted by the Coconut Research Institute (CRI) has proved that Gliricidia improves soil fertility and the microclimate in sustainable agriculture projects. Leaf litter covers the soil and reduces the soil temperature underneath the Gliricidia canopy, thereby increasing root activity, reducing soil moisture losses and reducing soil carbon oxidation. Soil from the Gliricidia-Coconut inter-cultivation has a greater proportion soil nutrients than in Coconut mono-cropping system (Table 4). The trials conducted by the CRI have identified Gliricidia as the best tree species for fixing biological nitrogen in the soil, enhancing soil fertility and encouraging the soil rehabilitation capacity (Anon, 2004). Soil from the mixed cropping area of coconut palms and Gliricidia inter-cultivation had a greater proportion of soil carbon, and high $\mathrm{N}$ and Ca levels were identified over leaves. Compared to coconut monoculture, the incorporation of Gliricidia into the farming system produces the highest wood yield in the range of 15 to 30 m.t. per ha for 10,000 trees/ha densities

(www.scribd.com/doc/95318104). According to research conducted at the Tea, Rubber and Coconut Research institutions and the Department of Export Agriculture, a considerable diversification of cash crops has occurred from the originally introduced germplasms selected by growers. These crops have served to produce highyielding varieties that are also resistant to pests, disease and adverse climatic conditions (MoENR, 2009b).

\subsection{Scale up Multiple Benefits}

Multiple benefit approaches of the sustainable management of agroforestry increase yields, incomes, food security and climate resilience, protect biodiversity, and reduce greenhouse gas emissions, often simultaneously. The

Table 4. Effect of Gliricidia inter-cultivation on soil N, P, K, Ca and Mg.

\begin{tabular}{ccccccc}
\hline Situation & \multicolumn{2}{c}{$\mathrm{N}(\mathrm{ppm})$} & & $\mathrm{P}(\mathrm{ppm})$ & & $\mathrm{K} \%$ \\
& $0-15$ & $16-30$ & $0-15$ & $16-30$ & $0-1516-30$ & $0-1516-30$ \\
\hline Coconut only & 490 & 327 & 3.4 & Trace & $0.15-0.17$ \\
Coconut + Gliricidia & 644 & 471 & 8.1 & 5.6 & $0.23-0.26$ \\
\hline
\end{tabular}

Sources: http://projects.nri.org/biomass/conference_papers/sustainable_biomass_production_in_srilanka.pdf 
direct forms of production and the indirect mechanisms that promote enhanced and sustained production are fundamental to the traditional agroforestry systems in Sri Lanka. The ancient and locally adapted agroforestry system of home gardens, which presently occupy nearly $22 \%$ of the land area in Sri Lanka, offer wide range of products and several ecosystem services to users. The wood production from home gardens could reach 681,400 $\mathrm{m}^{3}$ in 2020 as expected in the Forestry Sector Master Plan of the country (MALF, 1995). Home gardens provide not only diverse fruit, vegetable, and spice products but also sources of mineral nutrients, particularly for women and children. Traditional systems of agroforestry of Kandyan Home Gardens (KHGs) that primarily contain perennial and semi-perennial trees, shrubs and more than 30 different crops contribute to local livelihoods and yield cash crops and products for subsistence use (Kallesoe \& De Alvis, 2005). The estimated mean technical efficiency for the spice based agroforestry production in Matale district in Sri Lanka is 84.32\%, which indicates that output could be further increased substantially (Lindara et al., 2004).

With the decline of village forests and access to local forest resources, farmers in Sri Lanka have learned to utilise agroforestry systems to meet household needs, reduce risks, diversify income streams and efficiently use the limited labour and financial resources. Indigenous fruit tree cultivation in agroforestry can have a significant effect on the health and nutrition of the rural communities, particularly the quality of child nutrition. Depending on the species, trees that shade crops to reduce evapotranspiration, erosion control and nutrient cycling are important in agroforestry systems (Albrecht \& Kandji, 2003). Smallholders in the Upper Mahaweli catchment of Sri Lanka use different production systems to occupy the alleys of contour hedgerows to control soil erosion. The Participatory Forestry Project (PFP) was implemented during 1993-2000 in Sri Lanka with the intent of reducing deforestation and improving household livelihoods by promoting co-management and agroforestry. The homestead garden subcomponent of the PFP was to improve livelihoods and the health status of poor families by providing alternative livelihoods in the forms of growing and selling timber and fruit (Kallesoe \& De Alvis 2005). According to the Forestry Sector Master Plan (FSMP) (1995), the projected wood production of peeler logs, saw logs and poles from home gardens and other non-forest tree resources would rapidly increase during the period from 2000 to 2020 in Sri Lanka (Table 5). The agroforestry programs implemented under the PFP created employment opportunities, raised income, reduced poverty and rehabilitated degraded areas. Gliricidia in agroforestry systems improves the soil fertility, improves the microclimate, and is ideal for fuel wood production under sustainable agriculture. Gliricidia presently produces fuel wood in the agro-based energy sector, such as for tea factories and desiccated coconut mills, to meet the overall energy security for the country. The production of leguminous soil enhancement, provision of animal fodder and production of biogas from Gliricidia coppice crops provide families with a fully integrated farming system. Growing leguminous trees and grass in mixed forage systems enhances the yield and quality of the understory grass and total output of the system. Gliricidia, on average, produces 23 m.t./ha of foliage that can be used as a soil mulch for improving soil fertility (Anon, 2004). Gliricidia, as a wood-based energy producer, is able to alleviate poverty, reduce foreign exchange and receive sufficient support from local technology (www.scribd.com/doc/95318104). Growing trees in home gardens and other agroforestry systems in Sri Lanka is promoted as a main strategy to supply wood and other forest products for meeting household and market needs. Sample surveys conducted on intercropping with coconuts listed the factors such as profitability, marketing facilities and convenience as the major reasons for farmers' preference for their selected crops for intercropping. Bananas, black and pineapple (in order) compose

Table 5. Projected wood production from home gardens and other non-forest tree resources (' $000 \mathrm{~m}^{3}$ ).

\begin{tabular}{|c|c|c|c|c|c|}
\hline Source/year & 2000 & 2005 & 2010 & 2015 & 2020 \\
\hline Peeler logs (rubber) & 7.9 & 8.3 & 8.4 & 8.2 & 8.2 \\
\hline \multicolumn{6}{|l|}{ Sawlogs } \\
\hline Home gardens & 582.7 & 631.3 & 681.4 & 731.7 & 769.2 \\
\hline Rubber & 256.3 & 269.9 & 270.0 & 263.3 & 265.8 \\
\hline Coconut and palmyra & 202.4 & 220.0 & 210.9 & 166.4 & 154.3 \\
\hline Trees on tea lands & 75.9 & 75.9 & 75.9 & 75.9 & 75.9 \\
\hline Other perennials & 68.6 & 71.7 & 74.9 & 78.3 & 81.9 \\
\hline Roadside planting & 4.8 & 5.0 & 5.1 & 5.2 & 5.2 \\
\hline \multicolumn{6}{|l|}{ Poles } \\
\hline Home gardens & 831.4 & 853.7 & 873.4 & 889.5 & 910.8 \\
\hline Other perennials & 47.7 & 49.9 & 52.1 & 54.5 & 57.0 \\
\hline
\end{tabular}

Source: FSMP (1995). 
pepper, coffee, ginger (in order) are the most preferred intercrops of farmers, while turmeric, betel, vegetables the second group (Liyanage et al., 1984).

\section{Policies for Agroforestry Adaptation}

\subsection{Changing Regulations and Legislation}

Sri Lanka has no strong obligations to the international climate change policy arena because the country neither emits a large quantity of greenhouse gasses (GHGs) that contribute to global warming nor is regarded as vulnerable to climate change (Yamane, 2009). However, there is a need to revise existing agriculture policy to take into account climate change impacts. New approaches to national policy for climate change adaptation under National Adaptation Programs of Action (NAPAs) are now being developed. It is suggested that the net emissions could be reduced by changing the current land uses to adopt better management practices of crop production and livestock farming. The introduction of trees into existing agriculture systems as agroforestry and the rehabilitation of degraded areas through tree planting are classified as eligible CDM projects under the Bonn Agreement. Food insecurity in Sri Lanka has also become an important policy issue that should be addressed due to its vulnerability to climate change impacts. The National Climate Change Adaptation Strategy (NCCAS) of Sri Lanka includes minimising climate change impacts on food security and safeguarding natural resources and biodiversity from climate change impacts. The Biodiversity Conservation Action Plan of 1999 in Sri Lanka recognised maintaining a high biodiversity of agricultural lands, especially in traditional farming systems, to increase future national agricultural productivity and to meet the challenges posed by climate change. The Commission on Sustainable Agriculture and Climate Change in 2011 has identified the policy changes and actions needed to achieve sustainable agriculture that contribute to food security and poverty reduction and to respond to climate change adaptation and mitigation goals. Farmers' dependency on evolving modern agriculture and government policies should be gradually replaced by self-confidence, self-motivation and the empowerment of integrating the sustainability of neglected centuries-old wisdom of traditional agriculture (Dharmasena, 2010). The framework of REDD+ reduces the unequal treatment of forests compared to agricultural crops and renders forest management more competitive with other forms of land use. The national REDD+ Program may help to demonstrate the value of agroforestry systems, gain the interest of potential investors, and popularise the enhancement of carbon stocks in home gardens and crop plantations (UN-REDD Programme, 2012). Inclusion of agriculture in climate change policies and inclusion of climate issues in agricultural policies are required to ensure cost-effective investments and offer benefits to the rural poor (Vermeulen et al., 2012). Adaptation measures and policies should be developed with the full participation of local communities and other stakeholders. The appropriate policy packages should cover aspects such as harvesting, processing, and utilisation of farmgrown wood and that ensure credit and extension services to popularise agroforestry among smallholder producers.

\subsection{Awareness Creation and Capacity Building}

Many farmers are aware of climate change but only few have a good understanding of the degree of uncertainty of climate change and impact projections. Unless they are educated in agroforest and climate change, they are susceptible to wrongly interpreting those projections. Scientifically backed technical strengths and community-based knowledge are the keys to developing effective adaptation strategies and reducing vulnerability of the natural resources and communities. Raising awareness and the development capacity of communities are vital tools for improving their understanding of the concept of climate change, their ability to effectively manage forest ecosystems and their livelihoods on a sustainable basis. The potential for carbon sequestration and an evaluation of the socio-economic benefits of carbon-offset projects of the forestry sector must be examined. Funding for research and advisory and vocational training schemes on agroforestry are of the utmost importance to develop ideas and new technologies that help farmers and forest producers prepare for the coming challenges. Outcomes of climate change research must be packaged and communicated via training programs, updates to grower field days, farm-forestry conferences, and farm-forestry project steering groups. Identification of the specific user needs through direct participation of farming communities is essential to determine the agro-meteorological services and actual value of forecasts for the systems. By developing a range of deliberate management techniques for agroforestry systems and enhancing management skills through participatory demonstration 
trials, farmers can produce quality products for specific market opportunities (Roshetko et al., 2007).

\subsection{Planning for Climate-Smart Agroforest Landscapes}

Climate-smart agriculture is one of the sustainable agriculture and rural development objectives of the Millennium Development Goals (MDGs) of reducing hunger and improving environmental management. The Commission on Sustainable Agriculture and Climate Change under the United Nations Framework Convention on Climate Change (FCCC) was set up to help develop climate-smart agricultural practices and achieve a food-secure world in the face of climate change. Developing countries require support of smallholder farming systems and the associated food systems to achieve food security due to the complications of climate change. Agroforestry is a set of innovative practices in which smallholder farmers may combat climate change by reverting to more natural productive systems that provide improved ecological and social functions. To accelerate the process of climate-smart production systems, science and traditional knowledge need to be integrated with necessary institutional and policy adjustments. According to the Secretariat to the Convention on Biological Diversity, the people in Sri Lanka continue to retain a reasonable stock of traditional knowledge and accumulated wisdom, which can be utilised to promote the sustainable use of biodiversity and to combat the problems of climate change. Interest in agroforestry is increasing due to its potential to address various on-farm adaptation needs with food shortages and the increased threat of climate change. Agroforestry products may generate financial capital beyond subsistence levels, thereby aiding capital accumulation and reinvestment at the farm level to strengthen the system's ability to cope with adverse impacts of a changing climate. Agroforestry under integrated landscape management approaches support food production, ecosystem conservation, and rural livelihoods across entire landscapes. Climate-smart agroforestry requires actions beyond the farm scale and working at the landscape scale to ensure inter-sectoral coordination and cooperation. The climate-smart agroforestry approach provides the opportunity for all relevant stakeholders to become involved in landscape planning, program implementation and progress monitoring (Scherr et al., 2012)

\subsection{No-Regret Options}

To address uncertainties, taking actions that offer significant development benefits under a range of climate scenarios are called "no-regret" options. These approaches, including promoting agroforestry systems, help maintain agricultural production and have obvious benefits with or without climate change (climate change building smallholder resilience.mht). New agroforestry models can help reduce uncertainty in local assessments of vulnerability to climate change. "No-regret" options provide economic benefits, simultaneously help to reduce GHG emissions, and provide additional environmental benefits, such as improvements in biodiversity protection, water management and soil quality (www.Copa-Cogeca.eu). In the Yan Oya watershed, which is in the dry zone of Sri Lanka, farmers have provided a unique opportunity to explore new land use patterns. Adaptation strategies consisting of no-regret options would be sustainable regardless of the magnitude of climate change. Both rainwater harvesting and restoration of existing tanks to promote agroforestry systems in Sri Lanka are "no regrets" adaptation methods that simultaneously deliver climate resilience and address current development needs. Integrating agroforestry characteristics into agro-well-based agriculture by using shallow groundwater provides the opportunity to cultivate perennial crops and seasonal crops throughout the year and is a new trend with farmers. Agroforestry as an adaptation option with lower life-cycle costs is known as a "no-regret" option because it will lower the cost of providing economic benefits and environmental services in Sri Lanka (Bhattacharya et al., 2003). Adaptation alternatives of agroforestry systems for climate change are "no regret" options for Sri Lanka because they are cost-effective and simultaneously address sustainable development goals. Some farmers maintain animal husbandry, such as rearing cows, under perennial crop systems. Shade and grass under trees can be converted to "agroforestry systems" that are more productive and effective land use systems compared to the conventional systems. These systems contribute unquantified and unvalued benefits to a farming household via vegetables, fruits, spices, firewood, timber, medicines, milk, shade, organic matter, fodder, soil moisture, wind breaks, and aesthetic value. Adaptation of these approaches by agroforestry systems support communities both in building resilience to a range of potential surprises and in adjusting to long-term climatic trends.

\subsection{Climate Change Adjustment Programs}

The Millennium Development Goals (MDG), which aim to reduce the number of hungry and desperately poor 
by at least half by 2015, could be supported by promising agroforestry pathways that increase on-farm food production and income (Garrity, 2004). Agroforestry in Sri Lanka contribute to the rehabilitation of degraded agricultural lands, increased yields of small holder farmers, and $\mathrm{CO}_{2}$ sequestration. Planning programs across the entire agroforestry system enable farmers to plan and prepare for challenges, such as prolonged drought, climate variability, biosecurity threats, emergency management and variable market conditions, and to sustainably manage their natural resource base. Forecasting the seasonal climate provides the opportunity for farmers to choose whether to opt for lower risk, lower return strategies or to adopt new technologies and intensify production (Vermeulen et al., 2012). Under the Climate Change Adjustment Program, farmers are provided with advice and a grant to develop a climate change action plan that outlines the aims and steps required to manage the impacts of climate change and improve the farm's long-term prospects

(www.daff.gov.au/climatechange/australias-farming-future/climate-change-adjustment-assistance). Developing countries are more vulnerable to climate change impacts due to the lack of economic and institutional capacities (Yamane, 2009). High investment costs of dedicated plantations and low biomass productivity are included in the main technical barriers to biomass production for energy in Sri Lanka (Bhattacharya et al., 2003). Management, in the case of climate change, of the agroforest environment must seek new models that enable fast and precise decisions. Sri Lanka has long been interested in the Clean Development Mechanism (CDM) financing of emission reduction projects; however, these projects pay more attention to vulnerable aspects of the country and adaptation to climate change (Yamane, 2009). Agroforestry farmers need mechanisms to provide incentives and reward their efforts to adapt as they face the uncertainties of climate change. The use of marginal cropland and degraded non-crop land for biomass production and energy, which lead to the co-benefits of soil and water conservation and land reclamation in Sri Lanka, are justified for financial incentives (Bhattacharya et al., 2003). Improved agroforestry systems that produce social and environmental benefits meet the conditions for eligible afforestation/reforestation (A/R) activities according to the Clean Development Mechanism (CDM) (Verchot et al., 2007). Management-intensive agroforestry systems that incorporate traditional chena farming in Sri Lanka would qualify for CDM projects.

\section{Conclusions and Recommendations}

Climate change impacts by complex weather-related phenomena have threatened agricultural and forest ecosystems and the livelihood of agricultural and local communities in Sri Lanka. Agroforestry in Sri Lanka has an important role in climate change adaptation through diversified land-use practices, sustainable livelihoods, sources of income, enhanced forest and agricultural productivity, and reduced weather-related production losses, which enhance resilience against climate impacts. Sustainable agroforestry management, along with raising awareness, strengthening technical capacities, creating policies for actions that encourage cross-sectoral and landscape approaches, is a key to helping agriculture- and forest-dependent people adapt to new conditions caused by climate change in Sri Lanka. Agroforestry activities on the ground that are aimed at climate change adaptation need to be developed and implemented through the involvement of a range of related sector agencies at local, national and international levels. The cooperation of those agencies is very important for the success of the strategies that are adapted to local circumstances.

\section{References}

Albrecht, A., \& Serigne, T. K. (2003). Carbon Sequestration in Tropical Agroforestry Systems. Agriculture, Ecosystems and Environment, 99, 15-27. http://dx.doi.org/10.1016/S0167-8809(03)00138-5

Anon (2004). Annual Report of the Coconut Research Institute (CRI) of Sri Lanka. Lunuwila: CRI.

Ariyadasa, K. P. (2002). Assessment of Tree Resources in the Homegardens of Sri Lanka. Bangkok, ECFAO Partnership Program on Information and Analysis for Sustainable Forest Management (2000-2002). http://www.fao.org/docrep/005/ac629e/ac629e00.htm

Basnayake, B. R. S. B., Abjhyasinghe, K. R., Sumathipala, W. L., Punyawardene, B. V. R. P., Perera, N., \& Joseph, P. G. (2007). Climate Change in Sri Lanka: Impacts, Adaptation \& Mitigation. Proceedings of the National Conference on Climate Change, Centre for Climate Change Studies, and Kobe-Asia-Pacific Network for Global Change Research, Department of Meteorology, Colombo, Sri Lanka.

Baba, N. (2010) Sinking the Pearl of the Indian Ocean: Climate Change in Sri Lanka. Global Majority E-Journal, 1, 4-16.

Bhattacharya, S. C., Salam, P. A., Pham, H. L., \& Ravindranath, N. H. (2003). Sustainable Biomass Production for Energy in 
Selected Asian Countries. Biomass and Bioenergy, 25, 471-482. http://dx.doi.org/10.1016/S0961-9534(03)00085-0

Booth, T. H., Jovanovic, T., Old, K. M., \& Dudzinski, M. J. (2000). Climatic Mapping to Identify High-Risk Areas for Cylindrocladium quinqueseptatum Leaf Blight on Eucalypts in Mainland South East Asia and around the World. Environmental Pollution, 108, 365-372. http://dx.doi.org/10.1016/S0269-7491(99)00215-8

Chandrapala, L. (1996). Long Term Trends of Rainfall and Temperature in Sri Lanka. In Y. P. Abrol, S. Gadgil, \& G. B. Pant (Eds.), Climate Variability and Agriculture (pp. 150-152). New Delhi: Narosa Publishing House.

Climate Change Secretariat (2010) Strengthening Capacity for Climate Change Adaptation, ADB TA 7326 (SRI), Climate Change Secretariat Ministry of Environment, Colombo, Sri Lanka.

Cruz, R. V., Harasawa, H., Lal, M., Wu, S., Anokhin, Y., Punsalmaa, B., Honda, Y., Jafari, M., Li, C., \& Huu, N. (2007). Asia Climate Change, 2007, Impacts, Adaptation and Vulnerability. In M. L. Parry, O. F. Canziani, \& J. P. Palutikof (Eds.), Contribution of Working Group II to the 4th Assessment Report of the Intergovernmental Panel on Climate Change (pp. 468). Cambridge: Cambridge University Press.

Dela, J. D. S. (1998). The Ecology and Social Biology of a Selected Population of the Western Purple-Faced Leaf Monkey. Ph.D. Thesis, Peradeniya: University of Peradeniya.

Dharmasena, P. B. (2010). Traditional Rice Farming in Sri Lanka. Economic Review, 36, 48-53.

Eriyagama, N., Smakhtin, V., Chandrapala, L., \& Fernando, K. (2010). Impacts of Climate Change on Water Resources and Agriculture in Sri Lanka: A Review and Preliminary Vulnerability Mapping. IWMI Research Report 135, Colombo: International Water Management Institute, 51-55. http://www.iwmi.cgiar.org/.../iwmi-research-report-135

Forestry Sector Master Plan of Sri Lanka (FSMP) (1995). Ministry of Lands, Agriculture and Forestry, Sri Lanka.

Garrity, D. P. (2004). Agroforestry and the Achievement of the Millennium Development Goals. Agroforestry Systems, 61, 5-17. http://dx.doi.org/10.1023/B:AGFO.0000028986.37502.7c

Jinapala, K. (2010) Overview: The Volume on Irrigation for Food Security. In P. Weligamage, G. G. A. Godaliyadda, \& K. Ji-napala (Eds.), Proceedings from the National Conference on Water, Food Security and Climate Change in Sri Lanka. www.iwmi.cgiar.org/... ations/Other/PDF/SLWC vol-1.pdf

Kallesoe, M., \& De Alvis, D. (2005) Financial Incentives for Ecosystem Conservation: A Review of the Development of Markets for Environmental Services in Sri Lanka. IUCN Water, Nature and Economics Technical Paper No. 4. IUCNThe World Conservation Union, Ecosystems and Livelihoods Group Asia, Colombo.

Kumari, M. A. S., Kansuntisukmongkol, K., \& Brockelman, W. Y. (2009). Plant Diversity in Home Gardens and Its Contribution to Household Economy in Suburban Areas in Sri Lanka. Environment and Natural Resources Journal, 7, 12-30.

Lindara, M. J. K. L., Johnsen, F. H., \& Gunatilake, H. M. (2004) Technical Efficiency in the Spice Based Agroforestry Sector in Matale, Sri Lanka. Noragric Working Paper No. 34, Noragric Agricultural University of Norway. http://www.eldis.org/vfile/upload/1/document/0708/DOC12243.pdf

Liyanage, M., Tejwani, K. G., \& Nair, P. K. R. (1984). Intercropping Under Coconuts in Sri Lanka. Agroforestry Systems, 2, 215-228. http://dx.doi.org/10.1007/BF00147035

Mattsson, E., Ostwald, M., Nissanka, S. P., \& Marambe, B. (2013). Homegardens as a Multi-Functional Land-Use Strategy in Sri Lanka with Focus on Carbon Sequestration. AMBIO, 42, 892-902. http://dx.doi.org/10.1007/s13280-013-0390-x

Mattsson, E., Ostwald, M., Nissanka, S. P., Holmer, B., \& Palma, M. (2009). Recovery and Protection of Coastal Ecosystems after Tsunami Event and Potential for Participatory Forestry CDM-Examples from Sri Lanka. Ocean \& Coastal Management, 52, 1-9. http://dx.doi.org/10.1016/j.ocecoaman.2008.09.007

Mattsson, E., Persson, U. M., Ostwald, M., \& Nissanka, S. P. (2012). REDD+ Readiness Implications for Sri Lanka in Terms of Reducing Deforestation. Journal of Environmental Management, 100, 29-40.

http://www.sifi.se/wp-content/uploads/2012/02/REDD \pm -readiness-implications-for-Sri-Lanka-in-terms-of-reducing-defore station.pdf http://dx.doi.org/10.1016/j.jenvman.2012.01.018

MALF (1995). Sri Lanka Forestry Sector Master Plan. Ministry of Agriculture, Lands and Forestry, Sri Lanka.

MoENR (2009a). National Workshop on Mainstreaming Climate Change for Sustainable Development in Sri Lanka.

MoENR (2009b). Fourth Country Report to the Convention on Biological Diversity.

Nanayakkara, V. (1991). Agroforestry Systems in Sri Lanka. In W. Mellink, Y. S. Rao, \& K. G. Mac Dicken (Eds.), Agroforestry in Asia and the Pacific (pp. 304). Bangkok: Winrock International.

National Communication (Natcom) (2000). Democratic Socialist Republic of Sri Lanka. Initial National Communication under the United Nations Framework Convention on Climate Change.

http://unfccc.int/national_reports/non-annex_i_natcom/items/2979.php

Näsström, R., \& Mattsson, E. (2009). Country Report Sri Lanka. Land-Use Change and Forestry at the National and Sub- 
National Level. Focali Report 2011:04, Gothenburg.

Nellemann, C., MacDevette, M., Manders, T., Eickhout, B., Svihus, B., Prins, A. G., \& Kaltenborn, B. P. (2009). The Environmental Food Crisis-The Environment's Role in Averting Future Food Crises. A UNEP Rapid Response Assessment. United Nations Environment Program, GRID-Arendal. http://www.grida.no

Nuberg, I. K., \& Evans, D. G. (1993). Alley Cropping and Analog Forests for Soil Conservation in the Dry Uplands of Sri Lanka. Agroforestry Systems, 24, 247-269. http://dx.doi.org/10.1007/BF00705625

Pandey, D. N. (2002). Carbon Sequestration in Agroforestry Systems. Climate Policy, 2, 367-377. http://www.climatepolicy.com http://dx.doi.org/10.3763/cpol.2002.0240

Peiris, T. S. G., Wijeratne, M., Ranasinghe, C. S., Anandacumaraswamy, A., Fernando, M. T. N., Jayakody, A., \& Ratnasiri, J. (2004). Proceedings from 2nd AIACC Regional Workshop for Asia and the Pacific, 2-5 November 2004, Traders Hotel, Pasay City.

Perera, M. (2010). Integrating Agro-Forestry Characteristics into Agro-Well-Based Agricuture. In P. Weligemege, G. G. A. Godaliyadda, \& K. Jinapala (Eds.), Irrigation for Food Security. Proceedings from the National Conference on Water, Food Security and Climate Change in Sri Lanka. Vol. 1.

http://www.iwmi.cgiar.org/Publications/Other/PDF/SLWC_vol-1.pdf

Punyawardena, B. V. R. (2007). Impacts of Climate Change on Agriculture in Sri Lanka and Possible Response Strategies: Impacts, Adaptation and Mitigation. Proceedings from National Conference on Climate Change 2007. www.ips.lk/.../308-climate-change-issues-in-sri-lanka

Ratnayake, U., \& Herath, G. (2005). Changes in Water Cycle: Effect on Natural Disasters and Ecosystems. Sri Lanka National Water Development Report. In N. T. S. Wijesekera, K. A. U. S. Imbulana, \& N. B. Paris (Eds.), World Water Assessment Program. Paris. www.ircwash.org/...ources/sri-lanka-national-water...

Responsible Tourism Partnership Sri Lanka (2008) Carbon-neutral Sri Lanka-Longhaul Destination of the Developing World, Colombo: Responsible Tourism Partnership Sri Lanka. www.allconferences.com/...erences/2011/20110124022808

Roshetko, J. M., Lasco, R. D., \& Angeles, M. S. D. (2007). Smallholder Agroforestry Systems for Carbon Storage. Mitigation and Adaptation Strategies for Global Change. World Agroforestry Center, 12, 219-242.

Scherr, S. J., Shames, S., \& Friedman, R. (2012). From Climate-Smart Agriculture to Climate-Smart Landscapes. Agriculture \& Food Security, 1, 12. http://www.agricultureandfoodsecurity.com/content/1/1/12

Sivakumar, M. V. K., Brunini, O., \& Das, H. P. (2005). Impacts of Present and Future Climate Variability on Agriculture and Forestry in the Arid and Semi-Arid Tropics. Climate Change, 70, 31-72. http://dx.doi.org/10.1007/s10584-005-5937-9

Somaratne, S., \& Dhanapala, A. H. (1996). Potential Impact of Global Climate Change on Forest Distribution in Sri Lanka. Water, Air, and Soil Pollution, 92, 129-135.

The World Bank Group (2011). Vulnerability, Risk Reduction, and Adaptation to Climate Change, Sri Lanka. Climate Risk and Adaptation Country Profile April 2011. The World Bank Group, Washington.

http://sdwebx.worldbank.org/climateportalb/doc/GFDRRCountryProfiles/wb gfdrr climate change country profile for LKA.pdf

UNESCAP (2007) Statistical Yearbook for Asia and the Pacific 2007. Thailand: United Nations Publication. http://www.unescap.org/stat/data/syb2007/ESCAP-SYB2007.pdf

UN-REDD Programme (2012) Sri Lanka REDD+ Readiness. Preparation Proposal, UN-REDD Programme Eighth Policy Board Meeting. http://www.unredd.net/index.php?option=com_docman\&task=doc

Verchot, L. V., Van Noordwijk, M., Kandji, S., Tomich, T., Ong, C., Albrecht, A., Mackensen, J., Bantilan, C., Anupama, K. V., \& Palm, C. (2007). Climate Change: Linking Adaptation and Mitigation through Agroforestry. Mitigation and Adaptation Strategies for Global Change, 12, 901-918. http://dx.doi.org/10.1007/s11027-007-9105-6

Vermeulen, S. J., Aggarwal, P. K., Ainslie, A., Angelone, C., Campbell, B. M., Challinor, A. J., Hansen, J.W., Ingram, J. S. I., Jarvis, A., Kristjanson, P., Lau, C., Nelson, G. C., Thornton, P. K., \& Wollenberg, E. (2012). Options for Support to Agriculture and Food Security under Climate Change. Environmental Science \& Policy, 15, 136-144. http://dx.doi.org/10.1016/j.envsci.2011.09.003

Weerakkody, U. (1996). Impact of Sea Level Rise on Beach Erosion and Inundation of Wetlands in the South-West Coast of Sri Lanka. Regional Workshop on Climate Change Vulnerability and Adaptation in Asia and the Pacific.

Wijeratne, M. A. (1996). Vulnerability of Sri Lanka Tea Production to Global Climate Change. Water, Air, and Soil Pollution, 92, 87-94.

Wijeratne, M. A., Anandacoomaraswamy, A., Amaratunge, M. K. S. L. D., Ratnasiri, J., Basnayake, B. R. S. B., \& Kalra, N. (2007). Assessment of Impact of Climate Change on Productivity of Tea (Camellia sinensis L.) Plantations in Sri Lanka. 
Journal of the National Science Foundation of Sri Lanka, 35, 119-126.

Yamane, A. (2009). Climate Change and Hazardscape of Sri Lanka. Environment and Planning, 41, 2396-2416. http://dx.doi.org/10.1068/a41213

Zubair, L., Hansen, J., Chandimala, J., Siraj, M. R. A., Siriwardhana, M., Ariyaratne, K., Bandara, I., Bulathsinghala, H., Abeyratne, T., \& Samuel, T. D. M. A. (2005). Current Climate and Climate Change Assessments for Coconut and Tea Plantations in Sri Lanka. IRI, FECT, NRMS and UoP Contribution to AS12 Project Report to Be Submitted to Start, Washington DC. 
Scientific Research Publishing (SCIRP) is one of the largest Open Access journal publishers. It is currently publishing more than 200 open access, online, peer-reviewed journals covering a wide range of academic disciplines. SCIRP serves the worldwide academic communities and contributes to the progress and application of science with its publication.

Other selected journals from SCIRP are listed as below. Submit your manuscript to us via either submit@scirp.org or Online Submission Portal.
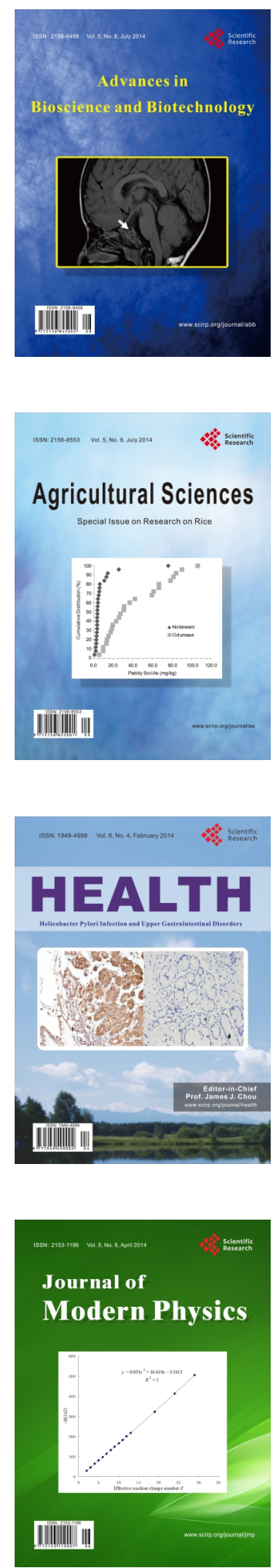
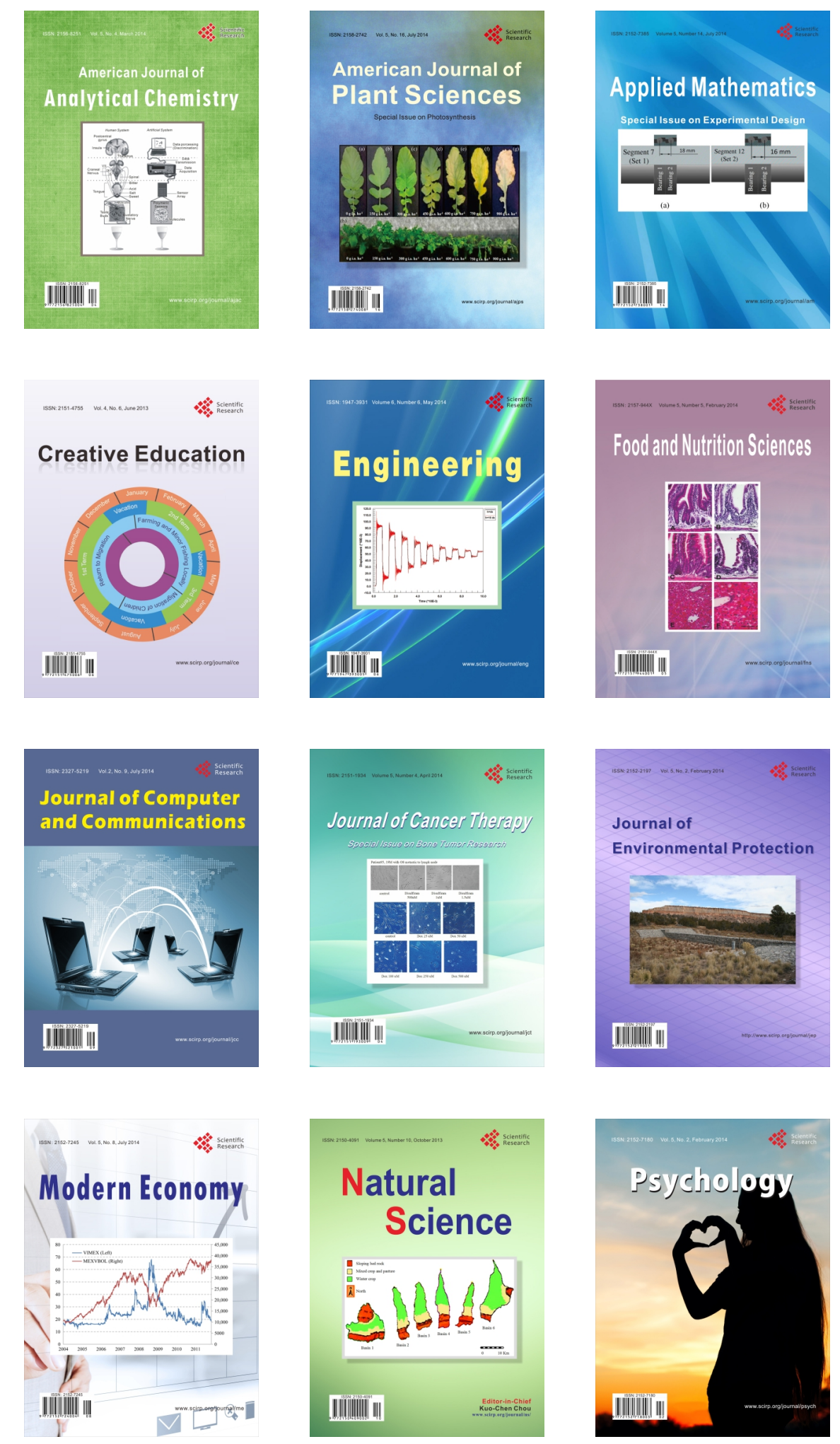